\title{
Evaluation of near-infrared reflectance spectroscopy (NIRS) for predicting chemical composition of straw silage
}

\author{
X. Liu ${ }^{1,2}$ and L. Han ${ }^{1,2}$, \\ ${ }^{1}$ College of Engineering, China Agricultural University \\ Beijing 100083, China \\ ${ }^{2}$ Key Laboratory of Modern Precision Agriculture System Integration, Ministry of Education \\ Beijing 100083, China
}

(Received 25 October 2005; revised version 7 January 2006; accepted 12 April 2006)

\begin{abstract}
A representative population of 157 straw silages was used as database for studying the possibilities of NIRS to predict chemical composition. NIRS calibrations were developed by means of modified partial least-squares (MPLS) regression. NIRS analysis of dried straw silages -provided accurate predictions of dry matter (DM), crude protein (CP), neutral detergent fibre (NDF), acid detergent fibre (ADF), hemicellulose, ash and lactic acid content as well as $\mathrm{pH}$, with correlation coefficients of crossvalidation $\left(\mathrm{R}_{\mathrm{cv}}^{2}\right)$ of $0.87,0.95,0.85,0.84,0.88,0.92,0.85$ and 0.96 respectively and standard error of cross-validation (SECV) of 23, 6, 22, 20, 14, 23, 6, $16 \mathrm{~g} \mathrm{~kg}^{-1} \mathrm{DM}$ and $0.06 \mathrm{~g} \mathrm{~kg}^{-1} \mathrm{DM}$ respectively. The NIRS technique could also accurately predict CP content, 0.91 (SECV: $7 \mathrm{~g} \mathrm{~kg}^{-1} \mathrm{DM}$ ), DM content, 0.92 (SECV: $18 \mathrm{~g} \mathrm{~kg}^{-1} \mathrm{DM}$ ) and $\mathrm{pH}, 0.94$ (SECV: $0.09 \mathrm{~g} \mathrm{~kg}^{-1} \mathrm{DM}$ ) of fresh straw silages.
\end{abstract}

KEY WORDS: near-infrared reflectance spectroscopy (NIRS), straw, silage, chemical composition

\section{INTRODUCTION}

As a traditional agricultural country, China has one of the largest straw resources in the world, with an output of more than 640 million tones annually. Straw silage constitutes the major conserved feed for ruminants in North China with maize stover being the most important material besides straw of rice, wheat and sorghum. The biochemistry of ensiling is complex and the chemical composition

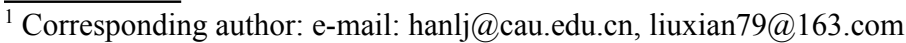


and nutritive value of silage may vary greatly depending on the nature of material, its stage of maturity, the use of silage additives and the ensiling method. Hence, before being feeded to the animal, the quality of silage should be evaluated in order to compose a balanced ruminant diet.

Compared to traditional chemical analysis, near infrared reflectance spectroscopy (NIRS) is rapid and cost efficient, without the destruction of samples and the use of hazardous chemicals. Over the last few years, NIRS has been extensively applied for evaluating chemical composition, digestibility, rumen degradability and fermentation characteristics of forages, grass silage and maize silage (Snyman and Joubert, 1992; De Boever et al., 1997; Park et al., 1998; Cozzolino et al., 2000; Andres et al., 2005). NIRS has been extensively used for the analysis of dried and ground feedstuffs since the early 1970s (Norris et al., 1976). However the drying procedure of silage before chemical or NIRS analysis is time-consuming and could cause loss of volatile substances (McDonald et al., 1991). So, in recent years researchers prefer to do a NIRS-analysis on the undried silage, although there remain other problems like the heterogeneity of the samples and the effect of water. In order to overcome this problem, Reeves and Blosser (1989) used dry ice or liquid $\mathrm{N}$ to grind the silage sample, but there is also very complicated. It was concluded that when not using dry ice, the undried silage samples treated in a wiley grinder gave better calibration results than that treated in a Hobart chopper and intact materails, and even intact silage samples could be used for CP determination (Reeves and Blosser, 1991).

This study aims to investigate the possibility of NIRS to predict the chemical composition of straw silage, and to establish NIRS calibrations on dried as well as fresh samples.

\section{MATERIAL AND METHODS}

\section{Collection and preparation of the silages}

A total of 157 straw and whole plant silage (maize, rice, wheat, sorghum) ensiled with or without silage additives (lactobacillus, enzyme, molasses and formic acid)and using different ensiling techniques (ensiling with silos, polyethylene bags and barrels), were sampled from cattle farms and laboratories of six provinces in China during 2003-2005. All the silages had a particle size between 2 and $10 \mathrm{~cm}$. The samples were frozen on the day of collection and stored until analysed. Prior to NIRS scanning of the fresh samples, the silages were thawed overnight at $4^{\circ} \mathrm{C}$ and cut in pieces of 2 to $4 \mathrm{~cm}$ in order to be packed easily in the sample cell. A subsample of each silage was dried in a forced-air oven at $65^{\circ} \mathrm{C}$ for $48 \mathrm{~h}$ and milled to pass a $1 \mathrm{~mm}$ screen for NIRS scanning and subsequent chemical analysis. 


\section{NIR scanning}

All work was performed on a NIRS system SPECTRUM ONE NTS (PerkinElmer, USA). The fresh silage samples were packed in a rotating circular quartz cell of $10 \mathrm{~cm}$ diameter. The dried and ground silage samples were scanned in small cups with a quartz window of $4 \mathrm{~cm}$ diameter. Each of the 157 silage samples was scanned three times as $\log 1 / \mathrm{R}$ over the wavelength range 1100 to $2500 \mathrm{~nm}$ at $2 \mathrm{~nm}$ intervals and the average spectrum was recorded.

\section{Wet chemical analysis}

Chemical analysis was carried out concurrently with the scanning. Dry matter (DM), ash, $\mathrm{pH}$ and crude protein $(\mathrm{CP})$ were analysed according to official methods (AOAC, 1990). Neutral detergent fibre (NDF) and acid detergent fibre (ADF) were analysed following the method of Van Soest et al. (1991); hemicellulose was obtained as NDF-ADF. The concentration of lactic, acetic, propionic and butyric acid and $\mathrm{pH}$ were determined on an aqueous extract of the silages. The acids were measured by HPLC (Saag, 1988) using a Hitachi GL C-610H column and UV detection at $210 \mathrm{~nm}$. All chemical analyses were done in duplicate and expressed on a dry weight basis.

\section{Statistical analysis}

The mathematical treatment of the spectral data was performed using Spectrum QUANT+ software (PerkinElmer, USA). NIRS calibrations were developed by means of modified partial least-squares (MPLS) regression (Shenk and Westerhaus, 1993). The following mathematical treatments were applied separately and simultaneously and then compared for choosing the best treatment combination: smoothing, derivative, standard normal variate and detrend (SNVD) and normal multiplicative scatter correction (NMSC). Cross-validation was carried out to select the optimal number of terms in the equation, so avoiding overfitting. The data set was sorted by the composition and took out one from four samples for validation sample, so the data set was divided in a calibration set of 117 samples and a validation set of 40 samples based on their composition. The mathematical treatment resulting in the lowest standard error of cross-validation (SECV) on the whole data set for each parameter was applied to the calibration set, and the resultant equation was used to predict the validation set. The following statistical parameters were considered: the correlation coefficient of calibration $\left(\mathrm{R}^{2}\right)$, the correlation coefficient of cross-validation $\left(\mathrm{R}_{\mathrm{cv}}^{2}\right)$, the standard error of calibration (SEC) and the standard error of cross-validation (SECV). Besides, the 
$\mathrm{SD} / \mathrm{SECV}$ ratio was calculated: when this ratio is greater than 2.5 , the equation is considered adequate for screening purposes, whereas a value greater than 5.0 is required for quality assurance (Murray, 1993). For the independent validation set the standard error of prediction (SEP), the correlation coefficient of validation $\left(\mathrm{R}_{\mathrm{v}}^{2}\right)$ and slope were considered.

\section{RESULTS AND DISCUSSION}

\section{Silage composition}

The mean, minimum, maximum value and standard deviation (SD) of the chemical parameters are summarized in Table 1 . The data set represented a wide range in composition. The correlation matrix between chemical parameters was calculated, and high correlations were found between $\mathrm{pH}$ and lactic acid (-0.73), acetic acid and propionic acid (0.71), NDF and ADF (0.66), DM and acetic acid $(-0.63), \mathrm{ADF}$ and $\mathrm{pH}$ (0.62). Similar good correlations of NDF and ADF were reported by Cozzolino et al. (2000) for 400 whole plant maize samples and by De Boever et al. (1997) for 101 maize silages.

Table 1 . The range in chemical parameters of the 157 straw silage samples in $\mathrm{g} \mathrm{kg}^{-1}$ on a dry weight basis

\begin{tabular}{lcccc}
\hline Parameter & Mean & Min & Max & SD \\
\hline Dry matter & 256 & 134 & 435 & 61 \\
Crude protein & 86 & 48 & 201 & 26 \\
NDF & 592 & 447 & 740 & 55 \\
ADF & 371 & 178 & 509 & 52 \\
Hemicellulose & 220 & 72 & 431 & 45 \\
Ash & 71 & 40 & 146 & 21 \\
pH & 3.97 & 3.60 & 5.23 & 0.34 \\
Lactic acid & 108 & 0 & 260 & 40 \\
Acetic acid & 54 & 0 & 162 & 27 \\
Propionic acid & 39 & 0 & 120 & 19 \\
Butyric acid & 10 & 0 & 117 & 22 \\
\hline
\end{tabular}

\section{NIR predictions}

The statistics of the calibrations with the lowest SECV on the whole data set and those of the corresponding calibrations on the calibration set are given in Table 2. The calibrations on the whole data set were good for all parameters, 
except for propionic acid. The values obtained for CP, NDF, ADF and lactic acid are in accordance with results reported by others (Snyman and Joubert, 1992; De Boever et al., 1997; Cozzolino et al., 2000). Comparison of the $\mathrm{R}^{2}$ on the whole data set with the $\mathrm{R}^{2}$ on the calibration set shows that all calibrations are robust, with exception of that for butyric acid.

Table 2. The calibration ( $\mathrm{n}=157$ and 117$)$ and validation $(n=40)$ statistics for the chemical parameters of dried straw silage samples in $\mathrm{g} \mathrm{kg}^{-1}$ on a dry weight basis

\begin{tabular}{|c|c|c|c|c|c|c|c|c|c|}
\hline & \multicolumn{5}{|c|}{ Calibration } & \multirow{2}{*}{\multicolumn{3}{|c|}{$\begin{array}{c}\text { Validation } \\
\mathrm{n}=40 \\
\end{array}$}} & \multirow{3}{*}{$\rho$} \\
\hline & \multicolumn{3}{|c|}{$\mathrm{n}=157$} & \multicolumn{2}{|c|}{$\mathrm{n}=117$} & & & & \\
\hline & $\mathrm{R}_{\mathrm{cv}}^{2}$ & SECV & $\mathrm{SD} / \mathrm{SECV}$ & $\mathrm{R}^{2}$ & SEC & $\mathrm{R}_{\mathrm{v}}^{2}$ & SEP & Slope & \\
\hline Dry matter & 0.87 & 23 & 2.7 & 0.86 & 22 & 0.90 & 23 & 0.81 & 8 \\
\hline Crude orotein & 0.95 & 6 & 4.7 & 0.95 & 5 & 0.93 & 8 & 0.98 & 8 \\
\hline $\mathrm{NDF}$ & 0.85 & 22 & 2.5 & 0.90 & 18 & 0.88 & 21 & 0.78 & 8 \\
\hline $\mathrm{ADF}$ & 0.84 & 20 & 2.6 & 0.86 & 20 & 0.83 & 20 & 0.80 & 4 \\
\hline Hemicellulose & 0.88 & 14 & 3.2 & 0.91 & 12 & 0.86 & 17 & 0.87 & 8 \\
\hline Ash & 0.92 & 6 & 3.7 & 0.95 & 5 & 0.92 & 7 & 0.81 & 7 \\
\hline $\mathrm{pH}$ & 0.96 & 0.06 & 5.7 & 0.98 & 0.05 & 0.90 & 0.09 & 0.83 & 6 \\
\hline Lactic acid & 0.85 & 16 & 2.6 & 0.83 & 17 & 0.64 & 21 & 0.78 & 4 \\
\hline Acetic acid & 0.81 & 12 & 2.3 & 0.85 & 11 & 0.69 & 15 & 0.76 & 8 \\
\hline Propionic acid & 0.28 & 16 & 1.2 & 0.36 & 16 & 0.11 & 18 & 0.19 & 2 \\
\hline Butyric acid & 0.68 & 10 & 2.3 & 0.90 & 6 & 0.66 & 8 & 0.76 & 2 \\
\hline
\end{tabular}

$\mathrm{R}_{\mathrm{cv}}^{2}$, the correlation coefficient of cross-validation; SECV, the standard error of cross-validation; $\mathrm{R}^{2}$, the correlation coefficient of calibration; SEC, the standard error of calibration; $\mathrm{R}^{2}$, the correlation coefficient of validation; SEP, the standard error of prediction; $\rho$, number of terms in the equation

The calibrations for DM, CP, NDF, ADF, hemicellulose, ash, and lactic acid have a SD/SECV ratio greater than 2.5 , indicating that they are adequate for screening. For $\mathrm{pH}$, the ratio is even higher than 5.0, making this calibration suitable for quantitative analysis. On the other hand, the ratio is lower than 2.5 for acetic, propionic and butyric acid, which means that these calibrations are less robust.

Concerning the independent validation, the correlation coefficient of validation $\left(\mathrm{R}_{\mathrm{v}}^{2}\right)$, the standard error of prediction (SEP) and slope are also shown in Table 2. The $\mathrm{R}_{\mathrm{v}}^{2}$ was high for DM, CP, NDF, ADF, hemicellulose, ash and $\mathrm{pH}$, and low for lactic, acetic, propionic and butyric acid. The worst results were for propionic acid, which is consistent with the calibration statistics.

Table 3 shows the statistics of the calibrations obtained with the fresh straw silage samples. High $\mathrm{R}_{\mathrm{cv}}$ values were found for DM, CP, NDF, ash, $\mathrm{pH}$ and 
Table 3. The calibration ( $\mathrm{n}=157$ and 117$)$ and validation $(\mathrm{n}=40)$ statistics for the chemical parameters of fresh straw silage samples in $\mathrm{g} \mathrm{kg}^{-1}$ on a dry weight basis

\begin{tabular}{|c|c|c|c|c|c|c|c|c|c|}
\hline & \multicolumn{5}{|c|}{ Calibration } & \multirow{2}{*}{\multicolumn{3}{|c|}{$\begin{array}{c}\text { Validation } \\
\mathrm{n}=40\end{array}$}} & \multirow{3}{*}{$\rho$} \\
\hline & \multicolumn{3}{|c|}{$\mathrm{n}=157$} & \multicolumn{2}{|c|}{$\mathrm{n}=117$} & & & & \\
\hline & $\mathrm{R}_{\mathrm{cv}}^{2}$ & SECV & $\mathrm{SD} / \mathrm{SECV}$ & $\mathrm{R}^{2}$ & SEC & $\mathrm{R}_{\mathrm{v}}^{2}$ & SEP & Slope & \\
\hline Dry matter & 0.92 & 18 & 3.4 & 0.93 & 17 & 0.88 & 20 & 0.82 & 7 \\
\hline Crude protein & 0.91 & 7 & 3.5 & 0.93 & 7 & 0.79 & 10 & 0.88 & 4 \\
\hline $\mathrm{NDF}$ & 0.82 & 23 & 2.4 & 0.81 & 24 & 0.66 & 31 & 0.71 & 9 \\
\hline $\mathrm{ADF}$ & 0.69 & 28 & 1.8 & 0.68 & 29 & 0.61 & 33 & 0.64 & 6 \\
\hline Hemicellulose & 0.79 & 20 & 2.3 & 0.75 & 20 & 0.69 & 26 & 0.71 & 8 \\
\hline Ash & 0.81 & 9 & 2.2 & 0.82 & 9 & 0.67 & 11 & 0.63 & 8 \\
\hline $\mathrm{pH}$ & 0.94 & 0.09 & 3.8 & 0.94 & 0.08 & 0.83 & 0.15 & 0.80 & 6 \\
\hline Lactic acid & 0.80 & 15 & 2.6 & 0.81 & 16 & 0.64 & 18 & 0.63 & 2 \\
\hline Acetic acid & 0.68 & 14 & 1.9 & 0.62 & 15 & 0.61 & 18 & 0.64 & 2 \\
\hline Propionic acid & 0.45 & 13 & 1.5 & 0.50 & 12 & 0.31 & 14 & 0.33 & 2 \\
\hline Butyric acid & 0.77 & 10 & 2.3 & 0.80 & 9 & 0.63 & 10 & 0.63 & 4 \\
\hline
\end{tabular}

lactic acid ranging from 0.80 for lactic acid to 0.94 for $\mathrm{pH}$. Moderate $\mathrm{R}_{\mathrm{cv}}^{2}$ values were obtained for ADF, hemicellulose, acetic and butyric acid. These results are comparable to or are a little poorer than those in the studies on fresh grass silages reported by Park et al. (1998) and Sinnaeve et al. (1994). The former successfully developed calibrations with 136 undried grass silages for ash, DM, NDF, ADF, $\mathrm{pH}$, acetic acid, butyric acid and lactic acid, with $\mathrm{R}_{\mathrm{cv}}^{2}$ of $0.87,0.96,0.93,0.90$, $0.91,0.73,0.83$ and 0.83 respectively. The latter using 56 fresh grass silages have also shown that it is possible to derive reasonable successful calibrations for $\mathrm{CP}$, ash, $\mathrm{pH}$, lactic acid and acetic acid. In our study a poor prediction was found for propionic acid, and similarly, Park et al. (1998) obtained a low $\mathrm{R}_{\mathrm{cv}}^{2}$ of 0.46 (SECV $0.38 \mathrm{~g} \mathrm{~kg}^{-1}$ fresh).

Considering the SD/SECV ratio, the calibrations for $\mathrm{CP}, \mathrm{DM}, \mathrm{pH}$ and lactic acid appear adequate for screening purpose. For each parameter, the prediction errors were higher than the calibration errors, which seems logic.

NIRS calibrations based on dried samples performed better than those based on fresh samples for mose parameters, but not for DM, propionic acid and butyric acid. The latter may be explained by losses of volatile substances, such as shortchain fatty acids and alcohols, during oven-drying (McDonald et al., 1991). Although it was accepted that the losses were kept at a minimum at $65-70^{\circ} \mathrm{C}$ (Deinum and Maassen, 1994), Jones (1981) indicated that freeze-drying could be the method of choice. An alternative approach had been applied by Snyman and Joubert (1992), which converted the fermentation acids to their corresponding salts with $\mathrm{H}_{2} \mathrm{SO}_{4}$ and NAOH before microwave drying and NIRS scanning. 
Nevertheless, the calibrations for DM, CP and $\mathrm{pH}$ based on either dried or fresh samples were good. For the other parameters, the lower accuracy of calibrations based on fresh samples may be due to the heterogeneity of the straw materials, particle size effects or spectral peak broadening by the large amount of water present.

Although NIRS analysis of fresh samples is less accurate, it is more convenient to use fresh than dried samples, allowing rapid prediction of the composition onsite without drying losses (Reeves and Blosser, 1991). Therefore, the decision depends on the circumstances and the individual needs of the user.

\section{CONCLUSIONS}

NIRS analysis of dried straw silages could provide accurate prediction of a wide range of chemical compositions, including DM, CP, NDF, ADF, hemicellulose, ash, $\mathrm{pH}$ and lactic acid. Also the NIRS technique could be used to accurately predict the DM, CP, $\mathrm{pH}$ and lactic acid of fresh straw silages. This study presented opportunities for the NIRS technique to characterize the feeding value of straw silages at different situations in the ruminant feeding system.

\section{ACKNOWLEDGEMENTS}

The authors gratefully acknowledge the helpfulness and expert suggestions from dr. J.L. De Boever from the department of Animal Nutrition and Husbandry of the Agricultural Research Center from the Ministry of the Flemish Community (Belgium).

\section{REFERENCES}

Andres S., Calleja A., Lopez S., Mantecon A.R., Giraldez F.J., 2005. Nutritive evaluation of herbage from permanent meadows by near-infrared reflectance spectroscopy: 2. Prediction of crude protein and dry matter degradability. J. Sci. Food Agr. 85, 1572-1579

AOAC, 1990. Association of Official Analytical Chemists, Official Methods of Analysis. 15th Edition. Washington, DC

Cozzolino D., Fassio A., Gimenez A., 2000. The use of near-infrared reflectance spectroscopy to predict the composition of whole maize plants. J. Sci. Food Agr. 81, 142-146

De Boever J.L., Cottyn B.G., De Brabander D.L., Vanacker J.M., Bouvque Ch.V., 1997. Prediction of the feeding value of maize silages by chemical parameters, in vitro digestibility and NIRS. Anim. Feed Sci. Tech. 66, 211-222

Deinum B., Maassen A., 1994. Effects of drying temperature on chemical composition and in vitro digestibility of forages. Anim. Feed Sci. Tech. 46, 75-86 
Jones D.I.H., 1981. Chemical composition and nutritive value. In: J. Hodgson, R.D. Baker, A. Davies, A.S. Laidlaw, J.D. Leaver (Editors). Sward Measurement Handbook. British Grassland Society, Hurley, Maidenhead, Berkshire, pp. 243-365

McDonald P., Henderson A.R., Heron S.J.E., 1991. The Biochemistry of Silage. 2nd Edition. Chalcombe Publications, Marlow, pp. 340

Murray I., 1993. Forage analysis by near infrared spectroscopy. In: J. Hodgson, R.D. Baker, A. Davies, A.S. Laidlaw, J.D. Leaver (Editors). Sward Measurement Handbook. British Grassland Society, Hurley, Maidenhead, Berkshire, pp. 285-312

Norris K.H., Barnes R.F., Moore J.E., Shenk J.S., 1976. Predicting forage quality by near infrared reflectance spectroscopy. J. Anim. Sci. 43, 889-897

Park R.S., Agnew R.E., Gordon F.J., Steen R.W.J., 1998. The use of near infrared reflectance spectroscopy on undried samples of grass silage to predict chemical composition and digestibility parameters. Anim. Feed Sci. Tech. 72, 155-167

Reeves III J.B., Blosser T.H., 1989. Near infrared reflectance spectroscopy for analyzing undried silages. J. Dairy Sci. 72, 79-88

Reeves III J.B., Blosser T.H., 1991. Near infrared spectroscopic analysis of undried silages as influenced by sample grind, presentation method and spectral region. J. Dairy Sci. 74, 882-895

Saag K., 1988. Determination of food additives by HPLC. In: HPLC in Food Analysis. R. Macrae (Editor). Academic Press. London, pp. 185-258

Shenk J.S., Westerhaus M.O., 1993. Monograph: Analysis of Agriculture and Food Products by Near Infrared Reflectance Spectroscopy. Infrasoft International, Port Matilda, PA (USA), pp. 103

Sinnaeve G., Dardenne R., Agneessens R., Biston R., 1994. The use of near infrared spectroscopy for the analysis of fresh grass silage. J. Near Infrared Spectrosc. 2, 79-84

Snyman L.D., Joubert H.W., 1992. Near-infrared reflectance analysis of the fermentation characteristics of silage prepared by chemical treatment to prevent volatilization of fermentation end products. Anim. Feed Sci. Tech. 37, 47-58

Van Soest P.J., Robertson J.B., Lewis B.A., 1991. Methods for dietary fiber, neutral detergent fiber and nonstarch polysaccharides in relation to animal nutriation. J. Dairy Sci. 74, 3583-3597 